\title{
Presidents, Legislators, and Foreign Policy in Latin America*
}

Pedro Feliú Ribeiro(1) and Flávio Pinheiro(2)**

\section{Abstract}

Which factors determine legislative support for the foreign policy initiatives of Latin American presidents? How do political parties and politicians behave when dealing with presidential foreign policy? The issue of whether presidents exercise greater influence over foreign or domestic affairs has been extensively debated in recent years, and the evidence indicates that legislators do behave differently when dealing with foreign policy proposals. Building on this debate, we analyse legislative support for the foreign policies of 22 Latin-American presidents in eight countries from 1994 to 2014, using an original dataset in a quantile regression framework. We also use three selected cases to illustrate our evidence. Our findings are counter-intuitive and bring new elements into the debate about legislative behaviour towards foreign policy in presidential countries. Measures of a political party's ideology, the size of the governing coalition, and the effective number of parties (ENP) play important roles in levels of legislative support for presidential foreign policy agendas. Surprisingly, the popularity of presidents and the nature of their initiatives - high or low politics - do not affect these levels of support.

Keywords: Foreign Policy Analysis; Domestic Actors; Latin American Politics; Legislative Behaviour; Presidential Systems.

\footnotetext{
* Received on 30 October 2015 and approved for publication on 25 January 2016.

** (1) University of São Paulo, São Paulo, SP, Brazil; pedrofeliu@usp.br; (2) University of São Paulo, São Paulo, SP, Brazil; pinheiro.f@usp.br.
} 


\section{Introduction}

Do presidents receive the same levels of support in their countries' legislatures for their domestic and foreign policy initiatives? And if not, which factors explain these variations? Both questions receive intensive attention in the literature on American politics and foreign policy analysis, which seek to explain presidential influence in particular spheres. However, they remain unexplored in respect of Latin American presidential systems, a lacuna which we will seek to fill.

According to Eshbaugh-Soha (2010), policy scope may significantly affect legislative support for presidential policies and programmes. In other words, ceteris paribus, a president may face either minor or major opposition in the legislature of his or her country, depending on the issue. The distinction between foreign and domestic politics is one of the most intensively discussed topics in the American politics literature (Milner and Tingley 2012). However, it remains unexplored in respect of combined presidential and multiparty systems, which occur in most Latin American countries. Analysing legislative procedures sheds some light on the distribution of political power in democratic regimes, and improves the evaluation of the performance of democratic institutions. Legislative support is regarded as a key element of political stability in constitutional democracies (Shugart and Carey 1992), especially by scholars who study presidential systems. This issue is particularly relevant in relation to Latin American countries, as several studies point out that disputes between presidents and legislatures play important roles in democratic breakdowns (González and Gillespie 1994; McCoy 1971; Santos 1986).

In this article, we record and analyse patterns of legislative support for 22 Latin-American presidents in eight countries from 1994 to 2014, with two objectives in mind. The first is to produce relevant 
and useful empirical data. We are not aware of other studies that have set out to record roll-call votes and analyse them in comparative perspective, which makes our descriptive exercise more valid and useful. The second is to estimate the impact of certain political and institutional factors on levels of legislative support for the foreign policies of Latin American presidents. In order to do so, and flowing from the nature of our data, we utilise the quantile regression framework. Quantile regression allows us to check the effect of our variables of interest at different points in the distribution. For example, we are more interested in analysing roll-call votes on bills that generate greater polarisation, and less interested in bills approved by consensus or quasi-consensus. By using quantile regression, we are able to recover the effects of the set of independent variables on distinct levels of legislative support for presidential foreign policy.

We find that the ideologies of political parties, the size of governing coalitions, and the effective number of parties (ENP) play important role in determining support for presidential foreign policy. Surprisingly, presidential popularity and the nature of the initiatives - high or low politics - do not play major roles. We regard these results as counter-intuitive since, contrary to theoretical predictions, large government coalitions and small ideological distances between parties tend to reduce support for presidential foreign policy initiatives. We explain this outcome in terms of the low costs of opposition legislators expressing themselves freely on these issues. In the case of large governing coalitions, other legislators and parties feel free to express their positions without having to fear the consequences of actual vetoes.

Alternatively, when the ideological distances among parties are relatively small, roll-call votes on non-budgetary policies such as foreign policy provide parties with opportunities to differentiate themselves from the others. We illustrate this with three recent cases. 
The first is the vote in the Brazilian National Congress on whether to support Venezuela's accession to the Mercado Común del Sur (Mercosur); the second, Colombian and Peruvian Congressional approval of a Free Trade Agreement (FTA) with the USA; and the third, the votes in Argentina, Brazil and Chile on whether to send troops to Haiti as part of the UN Stabilization Mission in Haiti (MINUSTAH).

In the next section, we discuss the literature on this subject covering the main causal arguments, and derive the theoretical hypotheses to be empirically tested. Following this, we describe the research design and methods used in the study, and provide basic information about the central variables in our explicative model. Next, we present the findings of our study, as well as three illustrative cases. Finally, we discuss our results and our contribution to the current literature.

\section{Legislative support for presidential foreign policy in the US and Latin America}

In this section, we explore two aspects of the literature about relationships among presidents, legislators, and foreign policy. First, we examine the literature on legislative support for presidential legislative initiatives on domestic and foreign policy, based on studies that provide the theoretical foundation for our econometric model. This literature is predominantly based on US presidentialism. Second, we explore studies of legislative support for Latin American presidents in particular; although this literature is not extensive with respect to foreign policy, there is a considerable body of work on executive-legislative relations, which played a key role in the formulation of our theoretical hypotheses. 
Presidents, Legislators, and Foreign Policy in

Latin America

\section{Legislative support for presidential domestic and foreign policy initiatives}

Legislative behaviour on foreign policy issues features prominently in the literature, but until recently the conclusions were far from clear. In particular, the study of legislative voting patterns and presidential foreign policy is part of a large literature within Anglo-American political science (Baldwin and Magee 2000; Conley 1999; Dahl 1950; Edwards 1990; Lindsay and Ripley 1992; Meernik 1993; Xie 2006). It yields two competing perspectives. The first, labelled 'bipartisanship' and the 'two presidencies' thesis, argues that the political dispute between domestic groups 'stops at the water's edge' (McCormick and Wittkopf 1990). It holds that the anarchy generated by the international system produces incentives for political parties to adopt unified positions on the foreign policies pursued by executives, in contrast with their behaviour towards domestic politics (Bjereld and Demker 2000). Thus domestic politics are characterised by high levels of party polarisation and political disputes, and international politics by low levels of party polarisation as well as political consensus (King 1986).

The 'two presidencies' thesis was first developed by Wildavsky (1966), who asserted that presidents are able to achieve greater success in foreign policy because executives have constitutional and institutional advantages over legislatures when dealing with foreign affairs. In this perspective, legislatures effectively delegate their powers to executives, as the latter work with specialised bureaucracies, and take advantage of the information asymmetry between these two branches of government. Thus, the result may create the impression of unified behaviour by both branches in relation to foreign policies (Ripley and Lindsay 1993). Opposition to presidential foreign policy may also be prejudicial to legislators, 
particularly party leaders, as they may be 'accused of treason' (Sinclair 1993).

Other scholars dispute this, arguing that legislatures tend to support domestic and foreign policies in the same way (McCormick, Wittkopf and Danna 1997). In this view, foreign policy is similar to any other public policy, and should not be distinguished. These analysts argue that foreign policy is subject to the same ideological and partisan disputes that characterise the domestic policy-making process. Contrary to the 'two presidencies' thesis, these scholars argue that the end of the Cold War gave rise to a significant decline in the level of foreign policy consensus between Democrats and Republicans in the USA (Canes-Wrone, Howell and Lewis 2008; Holsti and Rosenau 1986), thus negatively affecting support for presidential foreign policy initiatives (Kupchan and Trubowitz 2007).

These analyses are highly sensitive to historical context. Instead of legislatures or political parties delegating power to executives, increased polarisation in legislatures would strongly influence the foreign policy-making process (Fleisher et al. 2000). Scholars argue that domestic factors such as partisan disputes, constituency preferences (Hiscox 2002; Henisz and Mansfield 2006), interest groups (Fordham and McKeown 2003), and public scrutiny (Burgin 1994) play a central role in Congressional votes on American foreign policy.

Notwithstanding the debate about the 'two presidencies' thesis, Rudalevige (2002) and Mack, DeRouen and Lanoue (2013) suggest that a two presidencies effect may still operate in the presidential-congressional relationship. Some scholars have even found evidence of the 'two presidencies' thesis beyond roll-call votes. Marshall and Pacelle (2005) assert that the thesis is valid, and demonstrate that presidents adopt different strategies for issuing executive orders in respect of foreign and domestic policy. Canes-Wrone, Howell and Lewis (2008) argue that presidents have far 
more influence over foreign affairs than domestic affairs. Similarly, based on an analysis of US Supreme Court decisions, Yates and Whitford (1998) conclude that judges are more likely to support US presidents in respect of foreign policy than domestic policy.

Besides variations in legislative support for domestic and foreign policy, scholars have also examined variations across international themes. For instance, Prins and Marshall (2001) argue that national defence and international security ('high politics') are treated differently in the US Congress than trade policy or international cooperation ('low politics'). High politics, they argue, generates a greater consensus among legislators and parties. Thus not all presidential foreign policy initiatives will be treated equally by Congress.

\section{Legislative support for Latin American presidents}

One of the main debates about the Latin American democratisation process in the late 1980s centred on the institutional stability of emerging democratic regimes. Many scholars suggested that the combination of presidential regimes and multiparty systems would result in political instability, thereby impeding the continuity of the new democratic regimes (Mainwaring 1993; Stepan and Skach 1993). Although those pessimistic predictions were not realised (Pereira and Melo 2012), tensions between the executive and legislative branches of government remained central to analyses of Latin American presidential regimes (Alemán and Navia 2009). For this reason, studies of Latin American presidential institutions have focused on testing hypotheses that were first developed in the American literature and then adapted to the specificities of Latin American politics, especially the multiparty system.

The first factor used to explain legislative support for Latin American presidents is the size of their legislative coalitions, with 
analysts arguing that presidents who depend on a minority party or coalition face greater difficulties in putting forward their political agenda (Alcántara Sáez and García Moreno 2008; Figueiredo, Salles and Vieira 2011). This differs from the situation in the USA, where the president is supported by a single party. Instead, they argue, in multiparty presidential systems, analyses should focus on the size of presidential coalitions (Negretto 2006; Chasquetti 2001; Cheibub, Przeworski and Saiegh 2004). For this reason, when analysing the relationships between Latin American presidents and their legislatures, it is vital to take into account not only the size of the presidential party, but also its coalitions. This yields our first hypothesis, namely:

\section{Hypothesis 1: The larger the size of presidential coalitions in legislatures, the higher the proportion of favourable votes for presidential foreign policy initiatives.}

Other variables also have to be taken into account when considering legislative support for presidential initiatives. One of them is the ENP. It seems reasonable to assume that the greater the ENP, the more difficult it is for executives to form majority coalitions, and the more likely ideological polarisation will be; this obviously makes it more difficult for presidents to gain approval of their initiatives (Cox and McCubbins 2001; Montero 2009). Santos, Pérez-Liñán and Garcia Montero (2014) corroborate this view in respect of Latin American politics, which depend heavily on party coalitions. They argue that the high level of ideological dissociation among political parties in legislatures may result in weaker control over the legislative agenda by the executive. This leads to our second hypothesis, namely:

Hypothesis 2: The greater the ideological distance among parties in legislatures, the lower the proportion of favourable votes for presidential foreign policy initiatives. 
The literature also contains two other explanations of legislative support for presidential initiatives. The first centres on bicameralism, with analysts arguing that lower and upper houses deal with presidential initiatives in substantially different ways. For instance, Alemán and Calvo (2008) conclude that bicameral rule in Argentina favour presidents because the two houses of parliament treat presidential initiatives differently. This allows the executive to send bills to the house that is most like to approve it. Secondly, scholars present strong evidence that newly elected presidents enjoy better relations with their legislatures, expressed in higher levels of legislative support in periods immediately after elections; this is commonly referred to as the 'honeymoon period' (Mack, DeRouen and Lanoue 2013). In Latin America, empirical evidence supports the honeymoon argument (Altman 2000; Molinas, Pérez Liñán and Saiegh 2004; Alemán and Navia 2009; Cárdenas, Junguito and Pachón 2008), and disregarding it could lead to model specification problems.

Together with coalition size, a central factor that may explain legislative support for presidential initiatives is popular approval. This argument holds that if presidents enjoy high levels of popular approval, they will encounter less legislative opposition, as legislators who veto or oppose presidential initiatives will pay a high price for this (Rudalevige 2002). We have formalised this argument in Hypothesis 3. The positive correlation between popular approval and legislative support has been observed in Brazil (Mainwaring 1997), Uruguay (Altman 2000), and Argentina (Calvo 2007), yet there is no consensus in the literature on this issue. Some studies show a null or negative effect (Fleisher et al. 2000); for example, Alemán and Navia (2009) find no evidence of the impact of presidential popularity on legislative support in Chile.

\section{Hypothesis 3: Presidential popular approval rates are positively correlated with levels of legislative support.}


Although this study has a specific aim, namely to examine presidential success in foreign affairs, it may contribute to, and take advantage of, the emerging Latin American literature about legislative participation in and influence over the foreign policy decision-making process. The most relevant material are case studies which indicate that Latin American legislatures and legislators are influential actors in foreign policy, and that executives should take their preferences into account. ${ }^{1}$ We benefit from this literature in that it allows us to assume that legislatures are relevant foreign policy actors. We also seek to gain an understanding of individual legislative behaviour towards presidential foreign policy initiatives.

\section{Data and methods}

\section{Describing the data}

In order to identify the political determinants of support for the foreign policies of Latin American presidents, we use a common unit of analysis in the literature, namely roll-call votes (Mack, DeRouen and Lanoue 2013; Schraufnagel and Shellman 2001). Our sample comprises roll-call votes in eight Latin American countries: Argentina (2003-2014), Brazil (1995-2011), Chile (1994-2014), Colombia (2006-2013), Ecuador (2009-2012), Mexico (2006-2015), Peru (2008-2014), and Paraguay (2003-2012). The dataset is based on initiative, country and year. It only contains roll-call votes about presidential foreign policy initiatives, totaling 1 743 observations. The distribution of initiatives in each country is summarised in Figure 1.

In this study, the dependent variable is the Proportion of Favourable Votes (PFV) in legislatures for presidential foreign policy initiatives. This comprises the percentage of votes in favour of a single presidential initiative in either the lower or upper houses of parliament, taking absences into account. The aim is to measure the 


\section{Figure 1}

Proportion of favourable votes per country

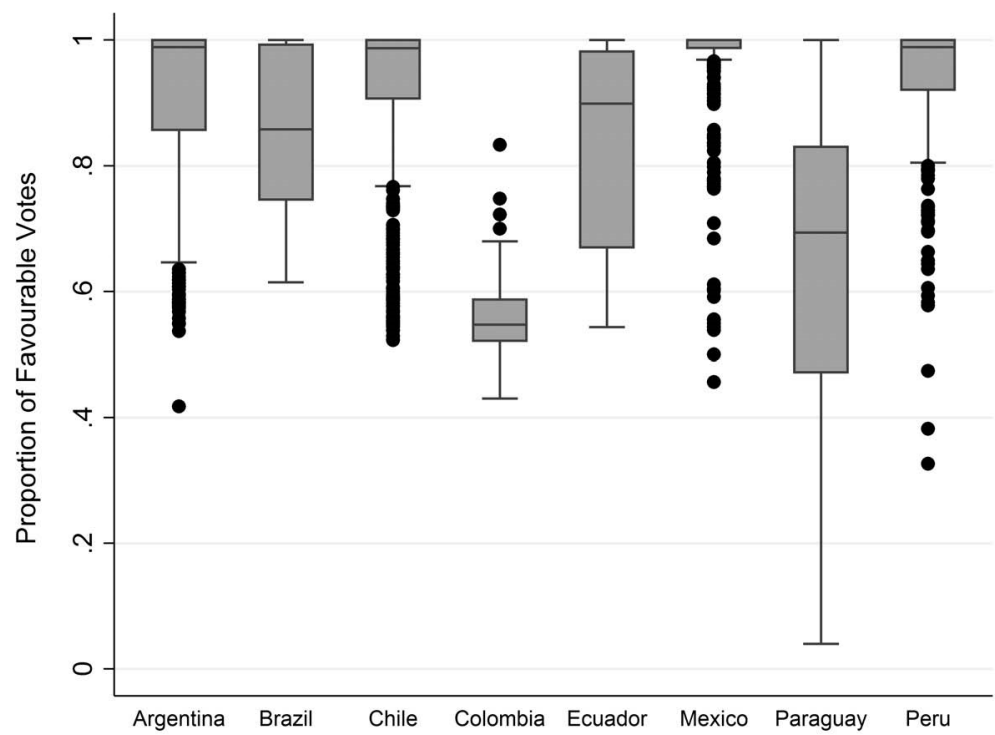

magnitude of support, instead of rejection or approval. We seek to explain not only variations in presidential support in general, but also specific foreign policy themes, such as high and low politics. The levels of support are quite high in all eight countries, but still differ considerably, ranging from 0.96 in Mexico and 0.92 in Chile to 0.64 in Paraguay and 0.83 in Ecuador. Additionally, variations increase when various themes are distinguished. Although our samples cover all foreign policy issues, we concentrate on analysing those which generate a high level of polarisation, which means that we expect to find evidence of our hypotheses in legislative votes on issues attracting low levels of consensus. The PFV distribution is presented in Figure 2, which shows that those initiatives are concentrated in the .25 and .50 quantiles - or below the median.

Except for Argentina and Colombia, information about roll-call votes was collected from official websites. ${ }^{2}$ Votes considered were 


\section{Figure 2}

Quantile distribution of dependent variable

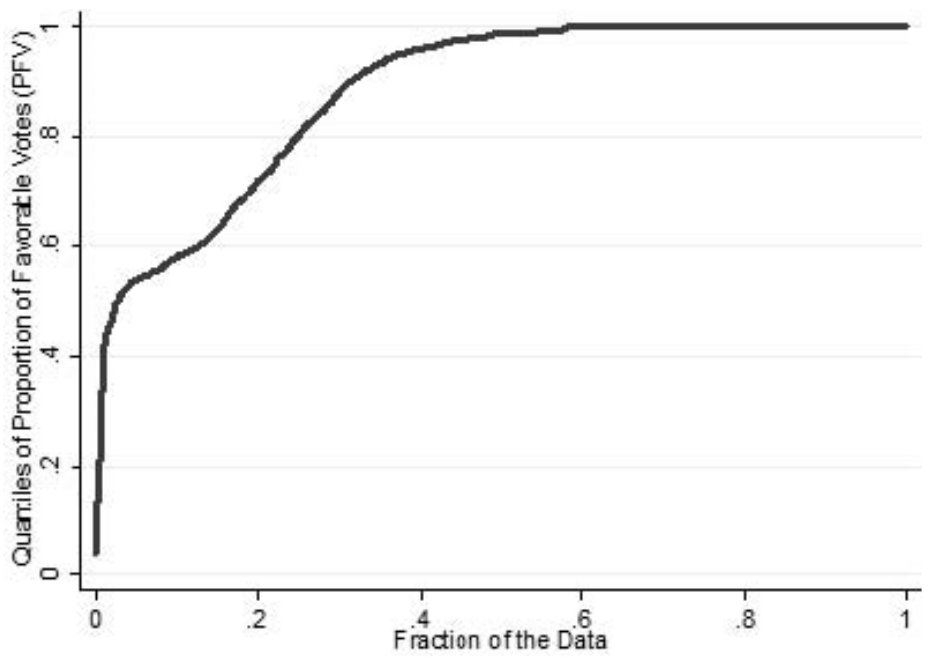

those on issues which contained direct references to foreign entities. Most of these initiatives involved international treaties, trade measures, domestic laws about the functioning of ministries of foreign affairs and diplomatic missions, and defence policy.

The frequency of foreign policy themes in our voting sample is presented in Table 1. It shows that diplomacy, trade policy, and defence were the most common issues. Under diplomacy, authorising the president to leave the country was frequent in Mexico

\section{Table 1}

Frequency of themes in legislative votes

\begin{tabular}{lcc}
\hline \hline \multicolumn{1}{c}{ Theme } & Frequency & Percentage \\
\hline Environment & 56 & 3.2 \\
Human Rights & 84 & 4.8 \\
Ed-H-T & 104 & 6.0 \\
Chancellery & 209 & 12.0 \\
Defense & 327 & 18.8 \\
Trade Policy & 466 & 26.7 \\
Diplomacy & 491 & 28.3 \\
\hline & 1,743 & 100 \\
\hline
\end{tabular}


Presidents, Legislators, and Foreign Policy in

and Peru, and memoranda of understanding between countries in all eight countries. In general, diplomacy comprises a broad array of diplomatic activities that are not covered under specific themes such as education, health and technology (Ed-H-T), human rights, and the environment

Trade policy, in turn, deals with the economic dimension of international relations; for example, votes on bilateral free trade agreements were common in Chile, Mexico, Colombia and Peru. The Paraguayan Congress often votes on accepting international loans, especially from the Inter-American Bank of Development (IADB) and the USA, and the legislatures in all eight countries under review voted frequently on bilateral agreements about the protection of foreign investments.

As regards defence, authorising national troops to leave the country and foreign troops to enter the country were common votes in most of the eight countries, but especially Argentina, Peru and Ecuador. All votes on military issues are recorded, as are weapons control treaties and international anti-terrorism agreements. Chancellery, representing $12 \%$ of our sample, encompasses issues about diplomatic services, well as international treaties such as cooperation over diplomatic visas. Presidential appointments of ambassadors also represent a significant amount of votes in this group. Finally, the remaining votes deal with international treaties about Ed-H-T, human rights, and the environment.

The independent variables are coalition size, presidential approval, ideological distance, ENP, high-low politics, and honeymoon period. ${ }^{3}$

Coalition size is measured in terms of the percentage of seats held by parties which officially support the government. Presidential approval comprises an average of presidential approval rates per year. ${ }^{4}$ Ideological distance reflects the differences among parties in 
every legislative period. We used the same strategy as Badillo (2007); the variable represents the difference between the most extreme value on the left and on the right, divided by nine. Ideological distance varies from 0 to 1 , and the closer to 0 , the lower the level of ideological polarisation. Except for Brazil, ${ }^{5}$ data on party positions were drawn from the Proyecto Elites Parlamentarias Latinoamericanas (PELA). ${ }^{6}$ ENP comprises the adjusted number of parties in a country's political system, calculated as follows: $N=\frac{1}{\sum_{i=1}^{n} P_{i}^{2}}$, where $\mathrm{N}$ is the number of parties with at least one seat, and $\mathrm{Pi}$ the square of the proportion of seats of every political party in the legislature (Laakso and Taagepera 1979). The ENP thus provides a weighted count of the number of parties. High-low politics is a dummy variable to identify votes related to defence, which is high politics and therefore coded 1, and trade policy and others, which are low politics and coded 0 . Finally, honeymoon period corresponds to the beginning of the presidential mandate. According to Mack, DeRouen and Lanoue (2013), this variable does not receive adequate attention in the literature, but may play an important role in presidential legislative support. Following Alemán and Calvo (2008), we coded the first years as 1 and all the others as 0 .

\section{Estimating presidential legislative support}

In order to test the hypotheses, we adopted a method that was flexible enough to allow a calculation of the heterogeneous effects of the independent variables of interest, with PFV along its own distribution. Dealing with PFV in this way allowed us to test our hypothesis in respect of polarised votes. The most appropriate way to respond to this research problem is the quantile regression framework introduced by Koenker and Bassett Jr (1978). Quantile regressions are a straightforward extension of the classical Ordinary 
Least Square (OLS) to estimate models based on the conditional quantile function. It employs a least absolute deviation estimator that can be used to estimate percentiles of the conditional distribution. Quantile regression detects distinct causal relationships for various points on the dependent variable distribution. The advantage of quantile regression is that it provides estimates of each covariate across the conditional distribution of the dependent variable. By contrast, traditional OLS regression delivers only one estimate, based on the conditional mean. An important characteristic of the quantile regression method is its ability to identify the presence of outliers within the dependent variable, because the estimation is a condition of the point position in the distribution of the dependent variable itself.

As briefly discussed above, our dependent variable has a very particular distribution. Most presidential initiatives were approved by more than $95 \%$ of votes, as shown in Figure 1. Additionally, it represents about $50 \%$ of the sample. Therefore, instead of focusing our attention on the average effect of the OLS, which could be biased by an uneven distribution, we estimate the effect of our independent variables at different moments of the distribution of the dependent variable. More specifically, we are interested in votes below the median, within the .25 and .50 quantiles. Substantively, those votes

\section{Figure 3}

Coalition size

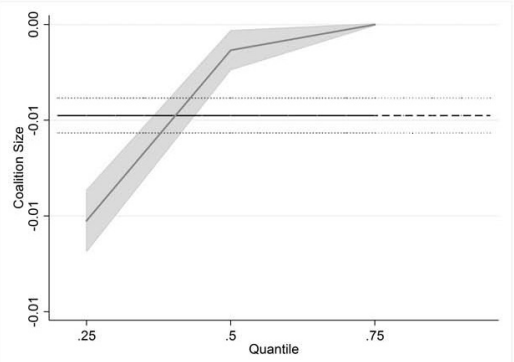

Figure 4

Effective number of parties (ENP)

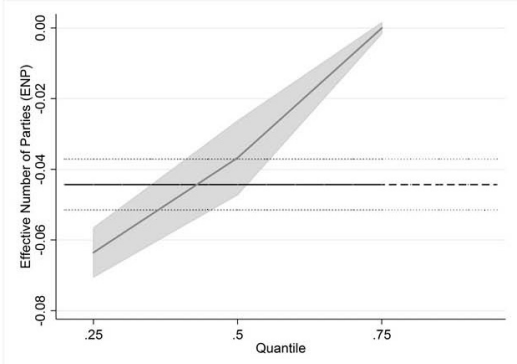


Figure 5

Ideological distance

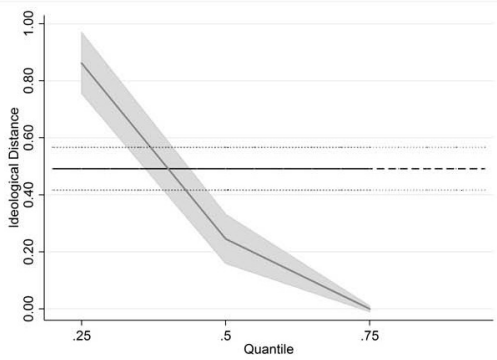

Figure 6

Popular approval

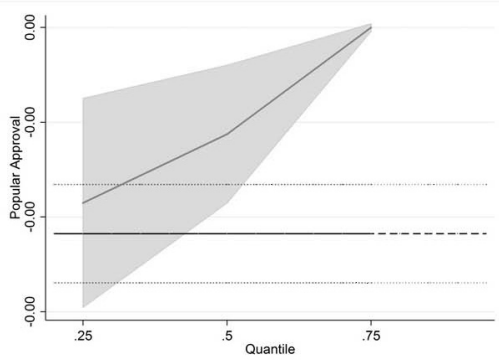

that are situated below the median deal with a more complex political context, as well as polarisation between the main political actors. Therefore, we conclude that the quantile regression framework would be the most effective tool for estimating the effect we have proposed, and testing our theoretical hypotheses. ${ }^{7}$

In the theoretical model, we have six independent variables of interest: coalition size, ENP, ideological distance, public approval of the president, honeymoon period, and high-low politics. Based on our results (which are shown in detail in Table 2 in the Appendix, and Figures 3 to 6), the last three variables had no effect on the PFV for both the OLS (the dotted lines on the graphs are the $95 \mathrm{CI}$, and the solid black line is the OLS estimate) and quantile regression models. For this reason, our efforts to explain the estimation outcomes and the relationship with the theoretical hypotheses will focus on the first three variables: coalition size, ENP, and ideological distance. These are statistically significant in both models, yet their effects are higher for the .25 and .50 quantiles rather than for the OLS estimate, and are not observed in the .75 quantile as expected. However, their practical meanings are more important.

Figure 3 shows that the bigger the government coalition, the lower the PFV, which means the president will receive less support for his 
initiatives from polarised votes. This result clearly contradicts Hypothesis 1, which states that the greater the size of the presidential coalition in the legislature, the greater the probability that the president's foreign policy initiatives will be approved. An explanation of this counter-intuitive finding may be found in the specific dynamics of the foreign policy debate. The possible costs of vetoing foreign policy initiatives are considered to be high, because they involve international commitments, and their consequences are therefore likely to be severe. Among other things, this explains the high rates of approval of and levels of consensus about presidential foreign policy initiatives. On the other hand, when the opposition faces a strong executive, based on a large coalition, the risks involving vetoes are low, and those parties and legislators may express themselves more freely. Given that foreign policy debates have become a vehicle for political parties to mark their ideological positions (Potrafke 2009), when the ruling coalition is large, an opportunity exists for opposition parties to stand out from their competitors on various votes, thereby lowering the PFV.

Figure 7 illustrates this argument empirically. All the foreign policy votes in the eight countries in which up to $80 \%$ of votes on presidential initiatives were favourable - the first quartile - are represented. Votes have been disaggregated to the level of individual legislators in order to capture the divisions between government and opposition on the floor. The percentage of positive and negative votes is recorded on the vertical axis, and the affiliation of the legislator's political party with the government or opposition coalition on the horizontal axis.

The figure shows a clear government-opposition split on polarised votes in all eight countries. In other words, when the president receives less legislative support for his or her foreign policy initiatives, the votes against him/her come mainly from opposition parties. This finding illustrates the argument about strategic voting 


\section{Figure 7}

Votes on presidential foreign policy initiatives by coalition

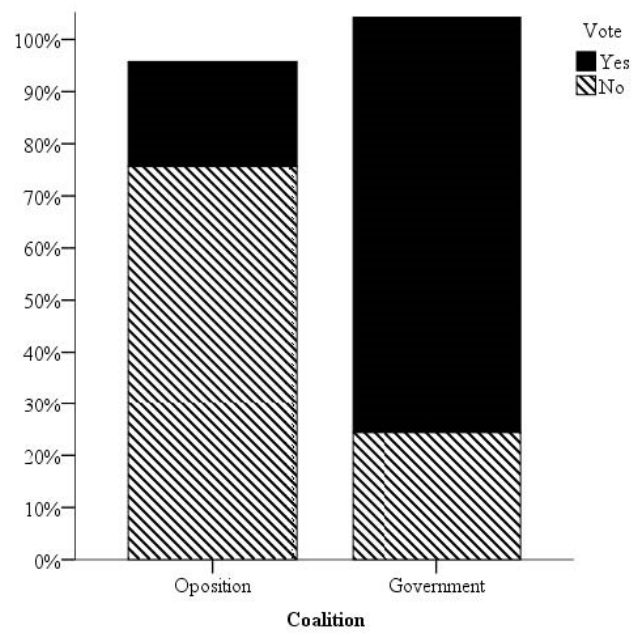

on foreign policy themes. In a strategic voting situation, opposition parties vote together against the governing party (or parties), regardless of whether they prefer the government proposal to the status quo. In other words, opposition members vote against the government to signal their general opposition, rather than their discontent with a particular proposal.

As regards the ENP variable, the findings corroborate our initial expectations. The number of political parties has a negative effect on the PFV, which shows that, for the .25 and .50 quantiles, the higher the ENP, the lower the PFV. Finally, while statistically significant, ideological distance presents a different result than expected. According to Hypothesis 2, the greater the ideological distance among parties in the legislature, the lower the chances of presidential foreign policy initiatives being approved; however, the evidence shows the opposite. The logic behind the finding is counter-intuitive, and similar to Hypothesis 1. When parties no longer differ over 
Presidents, Legislators, and Foreign Policy in

domestic and mostly economic issues, they tend to make their ideological identities felt in other, non-budgetary, policy fields, such as foreign policy. For this reason, during polarised votes, when the ideological distance among political parties is smaller, the PFV decreases.

Although our findings do not confirm our hypotheses, the results are still highly relevant. First, we confirm the salience of coalition size, ENP, and ideological distance in explaining support for presidential foreign policy initiatives in polarised votes. Second, the outcomes can be explained with a coherent argument, and illustrated with selected cases.

\section{Illustrating the findings with three cases}

To illustrate the empirical relationship established above, we present in this section the analysis of three cases: sending troops to Haiti from Brazil, Argentina and Chile, the approval of the entrance of Venezuela into the Mercosur, and the approval of the FTA by Chile, Colombia and Peru with the United States. We have chosen these three cases for two main reasons. First, security and trade issues are the most frequent subjects of presidential initiatives in foreign policy for the .25 quantile of our sample. Second, two of the cases involve several countries.

First, we deal with the decisions to assign Argentinian, Brazilian and Chilean soldiers to the UN Stabilization Mission in Haiti (MINUSTAH) - an important foreign policy issue for all three countries. These presidential initiatives received massive support from ruling parties, but were strongly opposed by opposition parties in both lower and upper houses of their legislatures.

In Brazil and Argentina, leftist parties such as Partido Socialismo e Liberdade (PSOL) and Afirmación para una República Igualitaria 
(ARI) defended the traditional principle of non-intervention in the domestic affairs of other states, and linked the proposed initiative to support for North American imperialism towards Latin America. At the same time, right-wing opposition parties like Democratas (DEM) in Brazil and Unión Demócrata Independiente (UDI) in Chile opposed the proposed intervention on the grounds of its high costs, and its uncertain duration. In Brazil, opposition members from Rio de Janeiro argued that the military should be sent to combat the drug lords in that city instead of to Haiti. On the other hand, members of the ruling parties in all three countries emphasised the importance of deepening regional integration in respect of security, and coordinating a UN mission in Southern Cone countries. Solidarity with a poor nation and regional stability were cited as reasons for supporting this presidential proposal.

Another issue where vote were split along ruling party-opposition lines was Venezuela's accession to Mercosur in the Brazilian parliament. The governing party leaders indicated to their benches that they would vote in favour, while the leaders of the two main opposition parties - Partido da Social Democracia Brasileira (PSDB) and DEM - indicated that they would vote against. The northern states of Brazil have a strong economic interest in Venezuela; as a result, almost all regional governors, including those belonging to PSDB, publicly supported its accession to Mercosur (Goldzweig 2013). However, except for two DEM members, the vast majority of members of those two opposition parties from the northern region voted against the proposal. Given that their constituencies would benefit from Venezuela's accession to Mercosur, this was clearly a strategic vote to demonstrate their opposition to the government rather than support for their preferred policy.

A close analysis of events in the Brazilian Senate, which approved the measure after its passage through the Chamber of Deputies, illustrates our argument. PSDB and DEM leaders spoke out sharply 
against the executive proposal to support Venezuela's accession, in many cases going against the preferences of their constituencies. For example, the PSDB senator for the northern state of Amazonas, Arthur Virgílio, declared that allowing Venezuela into Mercosur would represent the end of the economic bloc. He even acknowledged that he was voting against local business interests. Though the roll call vote was 35 to 27 in favour of the executive proposal, an apparently difficult result for the government, the specialised media had anticipated this result for some time, due to the size of the governing coalition and the pressures exerted by the governors of northern states on senators and representatives. For instance, in 2009, the governing coalition held $66 \%$ of seats in the Chamber of Deputies, while the PSDB and DEM held $40 \%$ of seats in the Senate. Additionally, at decisive stages in the Senate, such as roll-call votes in the Senate Committee on Foreign Relations on whether or not to allow the matter to do go to the floor, the governing coalition won by a considerable margin. This indicates that the fiery speeches by opposition members did not influence the outcome.

Both these cases reveal strategic voting on the floor. Opposing the president's international commitments can damage a legislator's public image. When the government holds a majority of the seats, the opposition may strategically vote against the president's initiative, publicly sustaining a different position to the status quo. In doing so, they present themselves as a substantive electoral alternative. Because the government holds the majority of the seats, and the proposal would therefore probably be approved, opposing the presidential proposals in question does not jeopardise the country's credibility in the international arena. This is why the greater the number of parties in the governing coalition, the greater the polarisation on the floor on Latin American foreign policy issues. The fact that opposition to presidential foreign policy initiatives has no chance of succeeding, and will therefore not affect the country in 
practice, opens the path for opposition parties to differentiate themselves from the current government, and present themselves as an alternative to the political status quo.

Finally, the FTA with the USA was strongly opposed by left-wing parties in Colombia and Peru. Relations with the USA is one of the main dimensions that divide left- and right-wing parties in Latin America, and this proved to be the case once again. In Colombia, opposition to the FTA in the Senate by the Partido Liberal de Colombia (PL) was particularly significant. Although the party had initially indicated that it would support the FTA, and had done so in Congress, PL and Polo Democrático Alternativo (PDA) senators staged a walkout when the issue reached the Senate. Opposition by the PL could be explained by the party's need to adopt an ideological stance in opposition to the right-wing governing coalition. Although the PL is labelled as a centre-left party, on the ideological scale presented by PELA, it is closer to the governing coalition than the PDA. Moreover, due to the government's majority in the Senate - in 2007, it controlled about $60 \%$ of Congress and Senate seats - the walkout could be interpreted as a risk-free and strategic mise-en-scène, responding more to the government-opposition logic than the ideological confrontation adopted by the PDA.

In Chile, however, eight right-wing Renovación Nacional (RN) legislators voted against the FTA, all from electoral districts in the south with two shared characteristics: levels of unemployment above the national average, and agrarian economies. In Chile, free trade usually does not polarise legislative behaviour, with both left- and right-wing coalitions supporting this foreign policy agenda.

The Colombian and Peruvian cases illustrate the relevance of ideological factors to legislative support for presidential initiatives. In both countries, left-wing parties voting against the FTA with the USA also confirmed their opposition to the government. This 
Presidents, Legislators, and Foreign Policy in

confirms that, when the ideological distance is clear, and it is possible to anticipate legislative behaviour, governing parties tend to act more cohesively in guaranteeing their support for the president's agenda.

\section{Concluding remarks}

We began this article with a question about foreign policy, more specifically about the executive-legislative relationship in respect of foreign affairs, as we sought to uncover the factors that impact on legislative behaviour towards presidential initiatives in the international arena. To this end, we proposed and followed an empirical agenda based on a wide and consolidated literature on issues such as foreign policy analysis, American politics, and Latin American politics. Our findings contradict explanations based on public presidential approval, high-low politics, or a honeymoon period. Instead, traditional explanations of executive-legislative relations such as coalition size, ideological distance, and ENP played a decisive role in our data. However, contrary to theoretical predictions, large government coalitions and short ideological distances among parties reduced support for presidential initiatives.

Our empirical work, as well as three cases show that, in the case of large ruling coalitions, other legislators and parties feel free to state their positions without having to fear the costs of vetoes. Put differently, when the opposition faces a strong executive- based on a large ruling coalition - the risks involving vetoes are low, and they may express themselves more freely. Since foreign policy debate has become a vehicle for political parties to establish their ideological positions, large government coalitions provide them with an opportunity to stand out, thereby reducing legislative support for presidential foreign policy initiatives. Moreover, in the case of major ideological divisions among parties, especially between ruling and 
opposition parties, ruling coalitions tend to behave more cohesively, resulting in increased legislative support for presidential initiatives.

\section{Acknowledgements}

The authors are grateful for the financial support provided by the National Council for Science and Technology Development (CNPq), process number 479342/2013-0; the Coordination for the Improvement of Higher Education Personnel (Capes); and the Center of International Negotiations Studies (CAENI) of the University of Sao Paulo.

\section{References}

Alcántara Sáez, Manuel and Mercedes García Moreno. 2008. 'Institutions and politicians: an analysis of the factors that determine presidential legislative success'. Working Paper no 348.

Alemán, Eduardo and Ernesto Calvo. 2008. 'Analyzing legislative success in Latin America: The case of democratic Argentina'. Working Paper, Woodrow Wilson Center.

Alemán, Eduardo and Patricio Navia. 2009. 'Institutions and the legislative success of "strong" residents: an analysis of government bills in Chile'. Journal of Legislative Studies 15(4): 401-419.

Altman, David. 2000. 'The politics of coalition formation and survival in multiparty presidential democracies: the case of Uruguay, 1989-1999'. Party Politics 6(3): 259-283.

Alexandre, Cristina Vieira Machado. 2006. 'O Congresso Brasileiro E a Política Externa (1985-2005).' MA Dissertation, Pontifícia Universidade Católica do Rio de Janeiro (PUC-Rio) / Instituto de Relações Internacionais (IRI).

Ardila, Martha, Leonardo Carvajal, Javier Garay, Margarita Marín, Javier Niño and José Ricardo Puyana. 2008. La Toma de Decisiones de La Política Exterior 
Presidents, Legislators, and Foreign Policy in Latin America

Colombiana. Bogotá: Universidad Externado de Colombia, Facultad de Finanzas, Gobierno y Relaciones Internacionales.

Badillo, Margarita Jiménez. 2007. 'Gobernando sin mayorías parlamentarias en América Latina’. Opinião Pública 13(1): 148-184.

Baldwin, Robert E and Christopher S Magee. 2000. Congressional Trade Votes: from NAFTA Approval to Fast-track Defeat. Washington, DC: Peterson Institute.

Bjereld, Ulf and Marie Demker. 2000. 'Foreign policy as battlefield: a study of national interest and party motives.' Scandinavian Political Studies 23(1): $17-36$.

Burgin, Eileen. 1994. 'Influences shaping members' decision making: Congressional voting on the Persian Gulf War'. Political Behavior 16(3): 319-342.

Bustamante, Gilberto Aranda and Jorge Riquelme Rivera. 2011. 'Los actores de la Política Exterior: el caso del Congreso Nacional de Chile.' Polis 10(28): 359-392.

Calvo, Ernesto. 2007. 'The responsive legislature: Public opinion and law-making in a highly disciplined legislature'. British Journal of Political Science 37(2): 263-280.

Canes-Wrone, Brandice, William G Howell and David E Lewis. 2008. 'Toward a broader understanding of presidential power: a reevaluation of the two presidencies thesis'. The Journal of Politics 70(1): 1-16.

Cárdenas, Mauricio, Roberto Junguito and Mónica Pachón. 2008. 'Political institutions and policy outcomes in Colombia: the effects of the 1991 constitution'. In Ernesto Stein, Mariano Tommasi, Carlos Scartascini and Pablo Spiller (eds), Policymaking in Latin America: How Politics Shapes Policies. Cambridge: Harvard University Press,

César, Susan Elizabeth Martins. 2002. 'Congresso Nacional e a Política Externa Brasileira'. MA Dissertation, Universidade de Brasília (UnB) / Departamento de Relações Internacionais.

Chasquetti, Daniel. 2001. 'Democracia, multipartidismo y coaliciones en América Latina: evaluando la difícil combinación'. In Jorge Lanzaro (ed), Tipos de Presidencialismo y Coaliciones Políticas en América Latina. Buenos Aires: CLACSO. 
Cheibub, José Antonio, Adam Przeworski and Sebastian M Saiegh. 2004. 'Government coalitions and legislative success under presidentialism and parliamentarism'. British Journal of Political Science 34(4): 565-587.

Conley, Richard S. 1999. 'Derailing presidential fast-track authority: The impact of constituency pressures and political ideology on trade policy in Congress'. Political Research Quarterly 52(4): 785-799.

Cox, Gary W and Mathew D McCubbins. 1997. 'Political structure and economic policy: the institutional determinants of policy outcomes', In Stephan Haggard and Mathew D McCubbins (eds), Structure and Policy in Presidential Democracies. New York: Cambridge University Press.

Dahl, Robert A. 1950. Congress and Foreign Policy. New York: WW Norton.

Diniz, Simone and Cláudio Oliveira Ribeiro. 2008. 'The role of the Brazilian Congress in foreign policy: an empirical contribution to the debate'. Brazilian Political Science Review 2(2): 10-38.

Edwards, George C. 1990. At the Margins: Presidential Leadership of Congress. New Haven: Yale University Press.

Eshbaugh-Soha, Matthew. 2010. 'The importance of policy scope to presidential success in Congress'. Presidential Studies Quarterly 40(4): $708-724$.

Figueiredo, Argelina Cheibub, Denise Lopes Salles and Marcelo Martins Vieira. 2011. 'Political and institutional determinants of the executive's legislative success in Latin America'. Brazilian Political Science Review 3(2): $155-171$.

Fleisher, Richard, Jon R Bond, Glen S Krutz and Stephen Hanna. 2000. 'The demise of the two presidencies'. American Politics Research 28(1): 3-25.

Flores, Rafael Velázquez. 2008. 'La Relación Entre El Ejecutivo Y El Congreso En Materia de Politica Exterior Durante El Sexenio de Vicente Fox: Cooperación O Conflicto?' Política Y Gobierno 15(1): 113-58.

Fordham, Benjamin O and Timothy J McKeown. 2003. 'Selection and influence: interest groups and congressional voting on trade policy'. International Organization 57(3): 519-549.

Goldzweig, Rafael Schmuziger. 2013. 'A Entrada da Venezuela no Mercosul: análise dos aspectos políticos e econômicos'. Revista de Iniciação Científica em Relações Internacionais 1(1): 2-29. 
Presidents, Legislators, and Foreign Policy in Latin America

González, Luis Eduardo and Charles Guy Gillespie. 1994. 'Presidentialism and democratic stability in Uruguay'. In Juan J Linz and Arturo Valenzuela (eds), The Failure of Presidential Democracy: The Case of Latin America. Baltimore: Johns Hopkins University Press.

González, Guadalupe. 2006. 'Las Bases Internas de La Política Exterior: Realidades y Retos de La Apertura Económica y la Democracia.' In Luis Herrera-Lasso (ed), México Ante El Mundo: Tiempo de Definiciones. México: FCE, pp. 155-235.

Henisz, Witold J and Edward D Mansfield. 2006. 'Votes and vetoes: the political determinants of commercial openness'. International Studies Quarterly 50(1): 189-212.

Hiscox, Michael J. 2002. 'Commerce, coalitions, and factor mobility: evidence from congressional votes on trade legislation'. American Political Science Review 96(3): 593-608.

Holsti, Ole R and James N Rosenau. 1986. 'Consensus lost, consensus regained?: foreign policy beliefs of American leaders, 1976-1980'. International Studies Quarterly 30(4): 375-409.

King, Gary. 1986. 'Political parties and foreign policy: a structuralist approach.' Political Psychology 7(1): 83-101.

Koenker, Roger and Gilbert Bassett Jr. 1978. 'Regression quantiles'. Econometrica: Journal of the Econometric Society 46(1): 33-50.

Kupchan, Charles A and Peter L Trubowitz. 2007. 'Dead center: The demise of liberal internationalism in the United States.' International Security 32(2): $7-44$.

Laakso, Markku and Rein Taagepera. 1979. 'Effective number of parties: a measure with application to West Europe'. Comparative Political Studies 12(1): 3-27.

Lindsay, James M and Randall B Ripley. 1992. 'Foreign and defense policy in Congress: a research agenda for the 1990s'. Legislative Studies Quarterly 17(3): 417-449.

Lemos, Leany. 2010. 'Brazilian Congress and Foreign Affairs: Abdication or Delegation?' GEG Working Paper 2010/58.

López Burian, Camilo. 2015. 'Political parties, ideology and foreign policy in Uruguay (2010-2014)’. Colombia Internacional 83 (January): 135-69. 
Lucero, Mariel R. 2007. 'El Poder Legislativo En La Definición de La Política Exterior Argentina: El Caso de Los Hielos Continentales Patagónicos.' Cuadernos Politca Exterior Argentina (CERIR) s/v (90): 1-109.

Mack, W R, Karl De Rouen and David Lanoue. 2013. 'Foreign policy votes and presidential support in Congress'. Foreign Policy Analysis 9(1): 79-102.

Mainwaring, Scott. 1993. 'Presidentialism, multipartism, and democracy: the difficult combination'. Comparative Political Studies 26(2): 198-228.

Mainwaring, Scott. 1997. 'Multipartism, robust federalism, and presidentialism in Brazil'. In Scott Mainwaring and Matthew Søberg Shugart (eds), Presidentialism and Democracy in Latin America. Cambridge: Cambridge University Press.

Marshall, Bryan W and Richard L Pacelle Jr. 2005. 'Revisiting the two presidencies: the strategic use of executive orders'. American Politics Research 33(1): 81-105.

Mena, Antonio Ortiz. 2004. 'O Processo de formulação da política de comércio nas Américas: lições da experiência Mexicana.' Revista Brasileira de Comércio Exterior s/v (79): 65-79.

McCormick, James M and Eugene R Wittkopf. 1990. 'Bipartisanship, partisanship, and ideology in congressional-executive foreign policy relations, 1947-1988'. The Journal of Politics 52(4): 1077-1100.

McCormick, James M, Eugene R Wittkopf and David M Danna. 1997. 'Politics and bipartisanship at the water's edge: a note on Bush and Clinton'. Polity 30(1): 133-149.

McCoy, Terry. 1971. 'Congress, the president, and political instability in Peru' In W H Agor (ed), Latin American Legislatures: Their Role and Influence Analysis for Nine Countries. New York: Praeger.

Meernik, James. 1993. 'Presidential support in Congress: Conflict and consensus on foreign and defense policy'. The Journal of Politics 55(3): $569-587$.

Milner, Helen V and Dustin H Tingley. 2012. 'Sailing the water's edge: where domestic politics meets foreign policy.' Unpublished manuscript, Princeton University, Harvard University.

Molinas, José, Aníbal Pérez Liñán and Sebastián Saiegh. 2004. 'Political institutions, policymaking processes, and policy outcomes in Paraguay, 1954-2003'. Revista de Ciencia Política (Santiago) 24(2): 67-93. 
Presidents, Legislators, and Foreign Policy in Latin America

Montero, Mercedes García. 2009. Presidentes y parlamentos: ¿ quién controla la actividad legislativa en América Latina? Madrid: Centro de Investigaciones Sociológicas.

Mustapic, Ana M and Mariana Llanos. 2000. 'El Papel Del Congreso Argentino en el Tratamiento del Presupuesto y el Mercosur.' In Gerardo Caetano and Rubén Perina (eds), Mercosur Y Parlamentos - Los Congresos En La Democracia Y La Integración. Montevidéo: Productora Editorial, pp. 51-76.

Negretto, Gabriel L. 2006. 'Minority presidents and democratic performance in Latin America'. Latin American Politics and Society 48(3): 63-92.

Neves, João Augusto de Castro. 2003. 'O papel do legislativo nas negociações do Mercosul e da ALCA.' Contexto Internacional 25 (1): 103-38.

Oliveira, Amâncio Jorge de and Janina Onuki. 2007. 'Empresariado e política comercial brasileira: atuação na arena legislativa'. Papéis Legislativos (Opsa/Iuperj) s/v (8): 1-21.

Pereira, Carlos and Marcus André Melo. 2012. 'The surprising success of multiparty presidentialism'. Journal of Democracy 23(3): 156-170.

Pinheiro, Flavio. 2008. 'Poder Legislativo e Política Externa: Um Estudo Sobre a Influência do Congresso Nacional do Chile na Formulação da Política Comercial durante a Década de 1990.' Contexto Internacional 30: 89-139.

Pinheiro, Flávio Leão. 2013. Poder Legislativo e Política Externa na América Latina. Buenos Aires: CLACSO.

Porcelli, Emanuel. 2010. 'Parlamento y política exterior: algunas reflexiones en torno a la "Ley del Azúcar"”. Meritum 5(2): 349-375.

Potrafke, Niklas. 2009. 'Does government ideology influence political alignment with the US? An empirical analysis of voting in the UN General Assembly'. The Review of International Organizations 4(3): 245-268.

Prins, Brandon C and Bryan W Marshall. 2001. 'Congressional support of the president: a comparison of foreign, defense, and domestic policy decision making during and after the Cold War'. Presidential Studies Quarterly 31(4): $660-678$.

Ribeiro, Pedro, Amâncio Jorge de Oliveira and Manoel Galdino. 2009. 'Política Externa Chilena e Espectro Ideológico Político-Partidário: um Estudo sobre a Câmara dos Deputados (2002-2006).' Dados 52(4): 835-70. 
Ripley, Randall B and James M Lindsay. 1993. Congress Resurgent: Foreign and Defense Policy on Capitol Hill, Vol. 6. Ann Harbor: University of Michigan Press.

Rudalevige, Andrew. 2002. Managing the President's Program: Presidential Leadership and Legislative Policy Formulation. Princeton: Princeton University Press.

Santos, Manoel Leonardo, Aníbal Pérez-Liñán and Mercedes Garcia Montero. 2014. 'El control presidencial de la agenda legislativa en América Latina.' Revista de Ciencia Política (Santiago) 34(3): 511-536.

Dos Santos, Wanderley Guilherme. 1986. Sessenta e Quatro: Anatomia da Crise. São Paulo: Vértice.

Sanchez, Leandro Enrique. 2015. 'El papel del Congreso Nacional de Argentina en la elaboración de la política exterior (1999-2003). Un modelo para su análisis.' Colombia Internacional 83: 103-132.

Schraufnagel, Scot and Stephen M Shellman. 2001. 'The two presidencies, 1984-98: a replication and extension'. Presidential Studies Quarterly 31(4): 699-707.

Shugart, Matthew Soberg and John M Carey. 1992. Presidents and Assemblies: Constitutional Design and Electoral Dynamics. New York: Cambridge University Press.

Sinclair, Barbara. 1993. 'Congressional party leaders in the foreign and defense policy arena'. In Randall B Ripley and James M Lindsay (eds), Congress Resurgent: Foreign and Defense Policy on Capitol Hill. Ann Arbor: University of Michigan Press.

Stepan, Alfred and Cindy Skach. 1993. 'Constitutional frameworks and democratic consolidation: Parliamentarianism versus presidentialism'. World Politics 46(1): 1-22.

Wildavsky, Aaron. 1966. 'The two presidencies'. Transaction 4: 7-14.

Xie, Tao. 2006. 'Congressional roll call voting on China trade policy'. American Politics Research 34(6): 732-758.

Yates, Jeff and Andrew Whitford. 1998. 'Presidential power and the United States Supreme Court'. Political Research Quarterly 51(2): 539-550. 
Presidents, Legislators, and Foreign Policy in

Latin America

\section{Appendix}

The equation to be estimated is given as follows:

$\mathrm{PFV}=\alpha \mathrm{i}+\beta 1$ IndependentVariables $+\pi \mathrm{it}$ (1) Assuming a linear specification for the $\tau$-th quantile,

$\mathrm{Q} \tau[. \mathrm{IX}=\mathrm{x}]=\alpha \mathrm{i}+\beta 1$ IndependentVariables $+\beta 2 \mathrm{PFV}+$ eit (2) In which

$$
\mathrm{Q} \tau \text { h. } \mid \mathrm{X}=\mathrm{x}]=\frac{\operatorname{Inf}}{\mathrm{P}}(. \leq \mathrm{q} \mid \mathrm{X}=\mathrm{x})_{\mathrm{q}}=\tau(3)
$$

is the $\tau$-th quantile conditional on distribution of the dependent variable.

\section{Table 2}

$O L S$ and quantile regression results

\begin{tabular}{|c|c|c|c|c|}
\hline & $\begin{array}{c}\text { (1) } \\
\text { OLS } \\
\mathrm{b} / \mathrm{se}\end{array}$ & $\begin{array}{c}\text { (2) } \\
\text { Quantile25 } \\
\text { b/se }\end{array}$ & $\begin{array}{c}\text { (3) } \\
\text { Quantile50 } \\
\text { b/se }\end{array}$ & $\begin{array}{c}(4) \\
\text { Quantile75 } \\
\text { b/se } \\
\end{array}$ \\
\hline Coalition Size & $\begin{array}{c}-0.005^{* * *} \\
(0.00)\end{array}$ & $\begin{array}{c}-0.010^{* * *} \\
(0.00)\end{array}$ & $\begin{array}{c}-0.001^{* * *} \\
(0.00)\end{array}$ & $\begin{array}{l}0.000 \\
(0.00)\end{array}$ \\
\hline ENP & $\begin{array}{c}-0.044^{* * *} \\
(0.00)\end{array}$ & $\begin{array}{c}-0.064^{* * *} \\
(0.00)\end{array}$ & $\begin{array}{c}-0.037^{* * *} \\
(0.00)\end{array}$ & $\begin{array}{l}0.000 \\
(0.00)\end{array}$ \\
\hline Ideological Distance & $\begin{array}{c}0.491^{* * *} \\
(0.04)\end{array}$ & $\begin{array}{c}0.862^{* * *} \\
(0.09)\end{array}$ & $\begin{array}{c}0.245^{* * *} \\
(0.03)\end{array}$ & $\begin{array}{l}0.000 \\
(0.00)\end{array}$ \\
\hline Popular Approval & $\begin{array}{c}-0.002^{* * *} \\
(0.00)\end{array}$ & $\begin{array}{c}-0.002^{* * *} \\
(0.00)\end{array}$ & $\begin{array}{c}-0.001^{* * *} \\
(0.00)\end{array}$ & $\begin{array}{l}0.000 \\
(0.00)\end{array}$ \\
\hline High-Low Politics & $\begin{array}{r}-0.005 \\
(0.01)\end{array}$ & $\begin{array}{c}-0.026 \\
(0.02)\end{array}$ & $\begin{array}{c}-0.010 \\
(0.01)\end{array}$ & $\begin{array}{l}0.000 \\
(0.00)\end{array}$ \\
\hline Honeymoon & $\begin{array}{l}-0.007 \\
(0.01)\end{array}$ & $\begin{array}{r}-0.012 \\
(0.02)\end{array}$ & $\begin{array}{c}-0.005^{*} \\
(0.00)\end{array}$ & $\begin{array}{l}0.000 \\
(0.00)\end{array}$ \\
\hline Constant & $\begin{array}{c}1.224^{* * *} \\
(0.03)\end{array}$ & $\begin{array}{c}1.348^{* * *} \\
(0.04)\end{array}$ & $\begin{array}{c}1.145^{* * *} \\
(0.03)\end{array}$ & $\begin{array}{c}1.000 * * * \\
(0.00)\end{array}$ \\
\hline$N$ & 1743 & 1743 & 1743 & 1743 \\
\hline
\end{tabular}


Pedro Feliú Ribeiro and Flávio Pinheiro

\section{Table 3}

Summary of statistics

\begin{tabular}{|c|c|c|c|c|}
\hline Variable & Mean & Std. Dev. & Min. & Max. \\
\hline \multicolumn{5}{|l|}{ Argentina } \\
\hline PFV & 0.90 & 0.15 & 0.42 & 1.00 \\
\hline ENP & 3.39 & 0.87 & 2.58 & 6.10 \\
\hline Ideological distance & 0.27 & 0.03 & 0.24 & 0.29 \\
\hline Coalition size & 52.36 & 6.63 & 33.50 & 62.20 \\
\hline Popular approval & 40.21 & 12.30 & 16.00 & 71.00 \\
\hline Observations & 312 & 312 & 312 & 312 \\
\hline \multicolumn{5}{|l|}{ Brazil } \\
\hline $\mathrm{PFV}$ & 0.86 & 0.13 & 0.61 & 1 \\
\hline ENP & 8.20 & 0.93 & 7.12 & 10.30 \\
\hline Ideological distance & 0.44 & 0.08 & 0.34 & 0.63 \\
\hline Coalition size & 66.87 & 7.75 & 56.10 & 77.20 \\
\hline Popular approval & 52.42 & 14.32 & 29.00 & 73.00 \\
\hline Observations & 26 & 26 & 26 & 26 \\
\hline \multicolumn{5}{|l|}{ Chile } \\
\hline $\mathrm{PFV}$ & 0.92 & 0.14 & 0.52 & 1.00 \\
\hline ENP & 5.46 & 0.32 & 4.81 & 5.83 \\
\hline Ideological distance & 0.50 & 0.05 & 0.43 & 0.63 \\
\hline Coalition size & 52.68 & 3.82 & 48.30 & 58.40 \\
\hline Popular approval & 43.43 & 13.54 & 23.00 & 78.00 \\
\hline Observations & 540 & 540 & 540 & 540 \\
\hline \multicolumn{5}{|l|}{ Colombia } \\
\hline PFV & 0.56 & 0.06 & 0.43 & 0.83 \\
\hline ENP & 6.16 & 1.34 & 4.98 & 8.50 \\
\hline Ideological distance & 0.48 & 0.00 & 0.48 & 0.48 \\
\hline Coalition size & $\begin{array}{l}0.40 \\
61.37\end{array}$ & 5.63 & $\begin{array}{l}0.40 \\
54.20\end{array}$ & $\begin{array}{l}0.40 \\
69.00\end{array}$ \\
\hline Popular approval & 61.03 & 12.09 & 40.00 & 76.00 \\
\hline Observations & 143 & 143 & 143 & 143 \\
\hline \multicolumn{5}{|l|}{ Ecuador } \\
\hline PFV & 0.83 & 0.16 & 0.54 & 1.00 \\
\hline ENP & 3.75 & 0.00 & 3.75 & 3.75 \\
\hline Ideological distance & 0.64 & 0.00 & 0.64 & 0.64 \\
\hline Coalition size & 59.60 & 0.00 & 59.60 & 59.60 \\
\hline Popular approval & 64.74 & 12.31 & 49.00 & 81.00 \\
\hline Observations & 53 & 53 & 53 & 53 \\
\hline \multicolumn{5}{|l|}{ Mexico } \\
\hline PFV & 0.97 & 0.09 & 0.46 & 1.00 \\
\hline ENP & 3.64 & 0.08 & 3.59 & 3.78 \\
\hline Ideological distance & 0.44 & 0.00 & 0.44 & 0.44 \\
\hline Coalition size & 40.60 & 0.00 & 40.60 & 40.60 \\
\hline Popular approval & 61.39 & 8.36 & 39.00 & 76.00 \\
\hline Observations & 424 & 424 & 424 & 424 \\
\hline \multicolumn{5}{|l|}{ Paraguay } \\
\hline PFV & 0.64 & 0.26 & 0.04 & 1.00 \\
\hline ENP & 3.30 & 0.12 & 3.18 & 3.42 \\
\hline Ideological distance & 0.09 & 0.04 & 0.05 & 0.14 \\
\hline Coalition size & 41.58 & 5.39 & 36.30 & 53.80 \\
\hline Popular approval & 47.19 & 15.60 & 11.00 & 86.00 \\
\hline Observations & 71 & 71 & 71 & 71 \\
\hline \multicolumn{5}{|l|}{ Peru } \\
\hline PFV & 0.92 & 0.13 & 0.33 & 1.00 \\
\hline ENP & 3.91 & 0.09 & 3.78 & 3.97 \\
\hline Ideological distance & 0.32 & 0.00 & 0.32 & 0.32 \\
\hline Coalition size & 48.65 & 12.21 & 30.00 & 56.60 \\
\hline Popular approval & 37.87 & 12.45 & 19.00 & 65.00 \\
\hline Observations & 174 & 174 & 174 & 174 \\
\hline \multicolumn{5}{|l|}{ Total Sample } \\
\hline PFV & 0.883 & 0.175 & 0.04 & 1.00 \\
\hline ENP & 4.449 & 1.247 & 2.579 & 10.3 \\
\hline Ideological distance & 0.413 & 0.121 & 0.05 & 0.641 \\
\hline Coalition size & 49.963 & $\begin{array}{l}0.121 \\
8.789\end{array}$ & 30 & $\begin{array}{c}0.011 \\
77.2\end{array}$ \\
\hline Popular approval & 49.045 & 15.432 & 11 & 86 \\
\hline Observations & 1743 & 1743 & 1743 & 1743 \\
\hline
\end{tabular}




\section{Table 4}

Descriptive statistics

\begin{tabular}{|c|c|c|c|}
\hline Variable & Levels & $\bar{N}$ & $\%$ \\
\hline \multicolumn{4}{|l|}{ Argentina } \\
\hline \multirow[t]{2}{*}{ Politics } & Low & 244 & 86.52 \\
\hline & High & 68 & 13.48 \\
\hline \multirow[t]{2}{*}{ Honeymoon } & No & 271 & 85.47 \\
\hline & Yes & 41 & 14.53 \\
\hline \multicolumn{4}{|l|}{ Brazil } \\
\hline \multirow[t]{2}{*}{ Politics } & Low & 15 & 57.70 \\
\hline & High & 11 & 42.30 \\
\hline \multirow[t]{2}{*}{ Honeymoon } & No & 12 & 46.15 \\
\hline & Yes & 14 & 53.85 \\
\hline \multicolumn{4}{|l|}{ Chile } \\
\hline \multirow[t]{2}{*}{ Politics } & Low & 417 & 77.22 \\
\hline & High & 123 & 22.78 \\
\hline \multirow[t]{2}{*}{ Honeymoon } & No & 452 & 83.70 \\
\hline & Yes & 88 & 16.30 \\
\hline \multicolumn{4}{|l|}{ Colombia } \\
\hline \multirow[t]{2}{*}{ Politics } & Low & 140 & 97.90 \\
\hline & High & 3 & 2.10 \\
\hline \multirow{2}{*}{ Honeymoon } & No & 94 & 65.73 \\
\hline & Yes & 49 & 34.27 \\
\hline \multicolumn{4}{|l|}{ Ecuador } \\
\hline \multirow[t]{2}{*}{ Politics } & Low & 47 & 88.67 \\
\hline & High & 6 & 11.33 \\
\hline \multirow[t]{2}{*}{ Honeymoon } & No & 53 & 100.00 \\
\hline & Yes & 0 & 0.00 \\
\hline \multicolumn{4}{|l|}{ Mexico } \\
\hline \multirow[t]{2}{*}{ Politics } & Low & 370 & 87.26 \\
\hline & High & 54 & 12.73 \\
\hline \multirow[t]{2}{*}{ Honeymoon } & No & 314 & 74.05 \\
\hline & Yes & 110 & 25.95 \\
\hline \multicolumn{4}{|l|}{ Paraguay } \\
\hline \multirow[t]{2}{*}{ Politics } & Low & 58 & 81.69 \\
\hline & High & 13 & 18.31 \\
\hline \multirow[t]{2}{*}{ Honeymoon } & No & 54 & 76.06 \\
\hline & Yes & 17 & 23.94 \\
\hline \multicolumn{4}{|l|}{ Peru } \\
\hline \multirow[t]{2}{*}{ Politics } & Low & 125 & 71.83 \\
\hline & High & 49 & 28.16 \\
\hline \multirow[t]{2}{*}{ Honeymoon } & No & 145 & 83.33 \\
\hline & Yes & 29 & 16.66 \\
\hline Total Sam & & & \\
\hline Politics & Low & 1416 & 81.24 \\
\hline & High & 327 & 18.76 \\
\hline Honeymoon & No & 1395 & 80.03 \\
\hline & Yes & 348 & 19.97 \\
\hline
\end{tabular}




\section{NOTES}

1. For Argentina, see Lucero 2007; Mustapic and Llanos 2000; Pinheiro2013; Porcellim 2010; Sanchez 2015. For Brazil, see Alexandre 2006; César 2002; Diniz and Ribeiro 2008; Lemos 2010; Neves 2003; Oliveira and Onuki 2007. For Chile, see Bustamante et al. 2011; Pinheiro 2008; Ribeiro et al. 2009. For Colombia, see Ardila et al. 2008. For Mexico, see Flores 2008; González 2006; Mena 2004. For Uruguay, see López 2015.

2. For Argentina, see http://www.decadavotada.com.ar/. For Brazil, see http://www.congressonacional.leg.br. For Chile, see http://www.congreso.cl/. For Colombia, see http://www.congresovisible.org/votaciones/. For Ecuador, see http://www.asambleanacional.gob.ec/es. For Mexico, see http://www.congreso.gob.mx/. For Paraguay, see http://www.congreso.gov. py/. For Peru, see http://www.congreso.gob.pe.

3. Tables 3 and 4 in the Appendix display the descriptive statistics of all variables presented in this study.

4. Argentina: Índece de Confianza en el Gobierno (ICG), Universidad Torcuarto Di Tella. Brazil: Instituto Brasileiro de Opinião Pública e Estatística (IBOPE). Chile: Centro de Estudios Públicos (CEP). Colombia: GALLUP. Ecuador: Perfiles de Opinión - only the the cities of Quito and Guayaquil. Mexico: Parametria. Paraguay: Mitofski. Peru: Instituto de Opinión Pública, Pontíficia Universidad Católica/ Datum.

5. Brazilian Legislative Survey, https://dataverse.harvard.edu/dataverse/bls.

6. http://americo.usal.es/oir/elites/.

7. A short formalisation of the estimated model is found in the Appendix.

\section{About the Authors}

Pedro Feliú Ribeiro is a professor at the Institute of International Relations of the University of São Paulo (IRI-USP), a researcher at the Centre of International Negotiations Studies (CAENI). He previously held positions at the Federal University of Paraiba in Brazil, and has been a visiting researcher at Birmingham University. His core disciplines are international relations and political science, and his current research focuses on foreign policy decision-making in Latin America. He has recently published 
articles on legislative behaviour, party unity and foreign policy in Latin America. He has also published in Revista Brasileira de Ciências Sociais, Brazilian Political Science Review, Revista Dados and Revista de Sociologia e Politica.

Flávio L Pinheiro holds a postdoctoral position at the Centre of International Negotiations Studies (CAENI), and a doctorate in international relations from the Institute of International Relations of the University of São Paulo (IRI-USP). His main area of interest lies at the intersection between comparative politics and international political economy, in the form of foreign policy analysis, legislative studies, partisanship, electoral studies, trade protection, and economic cooperation. He is the author of Poder Legislativo e Política Externa na América Latina (Ciudad Autónoma de Buenos Aires: CLACSO 2014). 